\title{
Rights and Slavery in Thomas Jefferson's Political Thought
}

\author{
Ari Helo \\ University of Helsinki
}

\begin{abstract}
Thomas Jefferson is famous for his advocacy of equal rights of men, religious freedom, and democracy throughout the United States. He is equally (in)famous for his racist statements, for his little concern for women's rights, for his apparently unrealistic anti-slavery policies, and for his strongly anti-Federalist politics. This article will make clear that his political solution to the problem of slavery was not as far-fetched at the time as many scholars still tend to think it was. His fame as the high priest of minimal government also needs to be reconsidered given his hugely expensive, governmental solution to the problem of slavery. It is also important to grasp how very restricted a role Jefferson attributed to the federal government in putting his abolition plan into effect. The only aspect concerning the federal government in Jefferson's plan had to do with financing and sending slaves abroad after each state's individual decision of emancipation.
\end{abstract}

Keywords: Thomas Jefferson; Human Rights; American History; Political History; Slavery; The Founding Era

\section{Introduction to the Problem}

This is how the Thomas Jefferson Foundation on its Monticello Organization website in 2020 formulated our essential dilemma in all history writing on Thomas Jefferson:

Thomas Jefferson helped to create a new nation based on individual freedom and selfgovernment. His words in the Declaration of Independence expressed the aspirations of the new nation. But the Declaration did not extend "Life, Liberty, and the pursuit of Happiness" to African Americans, indentured servants, or women. Twelve of the first eighteen American presidents owned slaves. Thomas Jefferson drafted the Declaration and called slavery an "abominable crime," yet he was a lifelong slaveholder. Fearful of 
dividing the fragile new nation, Jefferson and other founders who opposed slavery did not insist on abolishing it. It took 87 more years - and the Civil War, the Emancipation Proclamation, and the 13 th Amendment - to end slavery. ${ }^{1}$

It seems clear enough that there is a tension here between Jefferson the founding father of American democracy and Jefferson the slaveholder. And yet, we do not know for certain that in Jefferson's mind the rights to life, liberty, and the pursuit of happiness were not supposed to pertain to African Americans, indentured servants, or to women. I have never been offered evidence in the Jefferson archive that he ever opposed such an extensive interpretation of the Declaration, even if a number of minorities in the America of his time still lacked full civil and political rights. Jefferson believed in human progress, and if slavery was an "abominable crime," it could be abolished over time, just like other infractions against natural equality among human beings.

What, in fact, upholds this contradictory image of Jefferson's intellectual outlook is most scholars' constant failure to keep in sight two things. ${ }^{2}$ First, Jefferson's thought cannot be grasped without taking into account his commitment to the still only developing American democratic majority rule under which all social reforms had to be achieved, if ever. Second,

1 Monticello Organization (Thomas Jefferson Foundation) Website, "Thomas Jefferson: Liberty \& Slavery at https://www.monticello.org/slavery-at-monticello/liberty-slavery (accessed May 27, 2020). The author wishes to express his sincere thanks for the helpful comments offered by M. Andrew Holowchak, Kenny Marotta, Peter S. Onuf, and the commentators provided by the American Studies in Scandinavia. As always, the author alone carries the responsibility for the quality of the final product.

2 Offering any comprehensive list of the huge literature on Jefferson's allegedly contradictory character is impossible. See, for just few examples, several articles in Peterson, Merrill D. Peterson (ed.), Thomas Jefferson: A Reference Biography (New York: Charles Scribner's Sons, 1986) or in Peter Onuf (ed.), Jeffersonian Legacies (Charlottesville: University of Virginia Press, 1994) or in Frank Shuffelton (ed.), The Cambridge Companion to Thomas Jefferson (New York: Cambridge University Press, 2009); For the classic accusation of Jefferson's betraying all good things he ever preached, see Leonard Levy, Jefferson and Civil Liberties: The Darker Side (Cambridge, MA.: Harvard University Press, 1963); For works seeking at least some consistency in Jefferson's thought, see, for example, Richard K. Matthews's brilliant The Radical Politics of Thomas Jefferson: A Revisionist View (Lawrence: University Press of Kansas, 1984); Scholars no doubt will keep on writing books on Jefferson's both "noble" and his "quite evil" passions, as expressed by Andrea Miller, who refers to two 2012 Jefferson books, John Meacham's Thomas Jefferson: The Art of Power (noble) and Henry Wiencek's Master of the Mountain: Thomas Jefferson and His Slaves (evil) in her Opinion Editorial titled, "The contradictory life and legacy of Thomas Jefferson" in Texarkana Gazette, Dec. 21, 2012 at https://www.texarkanagazette.com/news/opinion/editorials/story/2012/ dec/21/contradictory-life-and-legacy-thomjeffers/264524/ (accessed May 28, 2020); For sheer lack of space here I limit my comments to those few scholarly works that deserve criticism. 
slavery was a hugely more complicated issue in the United States of the time than most scholars assume. Not only the South but almost all Northern states, under their varying programs of gradual emancipation, were still slave states during the famous Missouri Compromise of 1820.

My purpose here is only to understand Jefferson's antislavery position as he depicted it himself. It is an odd tendency among historians to still divide themselves into camps defending or accusing Jefferson for being what he was. What most often remains unresolved in any such approach is how he himself rationalized his own position as a party leader, a slaveholder, and a moral individual, who opposed slavery. Indeed, he talked a lot about morality and yet never asked forgiveness for being an antislavery slaveholder.

Understanding Jefferson can be a legitimate goal, even if the resulting picture cannot be reconciled with whatever it is that one sees as the focal point of an entity called American history. The focus on Jefferson's view of things has nothing to do with justifying him, only with understanding him. Neither does such an approach amount to addressing the enormity of slavery itself. The past is what it is. Only our historical understanding of it changes. For errors in understanding the past historians can only accuse other historians, not the dead. ${ }^{3}$ This is also why my approach occasionally includes criticism of other historians' views rather than those of Jefferson himself.

In the following I will show how Jefferson's at the time radical goal of emancipation of slaves figured in his political thought and how it changed shortly before the famous Missouri compromise. What never changed was that Jefferson's plan was to be implemented without the federal government intervening at all. I will begin with Jefferson's rights thinking, and then consider his thought on political rights in particular. Then I will point out that only by distinguishing Jefferson's racism from his moral thought and his antislavery stance can one begin to understand what his abolition plan was all about. It is important to grasp why his plan eventually changed to allow the extension of slavery to the West while waiting for the final, state-level political solution to emerge. As we will see, Jefferson had no federal plan to end slavery. Eventually his political solution did not emerge because Jefferson himself belonged to the minority in a system of majority democracy.

3 For a thorough discussion on the distinction between the past and history written about it, see Ari Helo, History, Politics, and the American Past: Essays on Methodology (New York: Routledge, 2020). 


\section{Jefferson's Rights Thinking}

Leonard Levy (1923-2006) famously held that Jefferson betrayed all his "libertarian" principles of minimal government and freedom, particularly given that in " 1800 or thereabouts the standards of his own time did not noticeably differ from those of ours on the kind of civil-liberties questions he confronted." ${ }^{4}$ I know of no evidence in the Jefferson archive (his thousands of memoranda, public speeches, and private letters) speaking to any modern libertarian stand of his. Neither is there much justification for his fame as a champion of any libertarian ideal of minimal government, as we will see later on.

Despite Levy's astonishing claim that civil-liberties questions were not different in 1800 from those of our day, it is notable that at the time there were very few, scattered ideas of bettering women's rights. Women were still generally viewed as completely dependent on the master of the household, be that a husband, a brother, or some other male relative. Alongside slaves, indentured servants (with very restricted civil rights) were still pouring into the country. Manorialism was in fact strengthening in some Northern states. There were serious tenant rebellions in the state of New York as late as the early1840s. ${ }^{5}$ Neither was Jefferson's nemesis, Alexander Hamilton, thinking in modern libertarian terms when suggesting that democracy was "our real disease," view the merchant as his "natural patron" and "representative."7

Let us consider the meaning of the Declaration of Independence as the allegedly libertarian slaveholder Thomas Jefferson himself most probably thought of it. To achieve this it is best to cling to Jefferson's original draft of the document regarding natural rights: "We hold these truths to be sacred $\&$ undeniable; that all men are created equal \& independant [sic], that from that equal creation they derive rights inherent $\&$ inalienable, among which

4 Leonard W. Levy, "Civil Liberties" in Peterson (ed.), Thomas Jefferson: A Reference Biography, 1986, 331-348, quote 347.

5 Manorialism was traditionally a system in which "the poor, defenseless, and landless were ensured permanent access to plots of land which they could work in return for the rendering of economic services to the lord who held that land." Editors, "Manorialism," Encyclopedia Briannica, https://www.britannica.com/ topic/manorialism (accessed Aug. 1, 2021); On the rebellions, see Charles W. McCurdy, Anti-Rent Era in New York Law and Politics, 1839-1865 (Chapel Hill: North Carolina Press, 2001).

6 Alexander Hamilton to Theodore Sedgwick, July 10, 1804 in Joanne B. Freeman, ed., Alexander Hamilton Writings (New York: The Library of America, 2001), 1022.

7 Alexander Hamilton, Federalist No. 35, ibid., 214-215. 
are the preservation of life, \& liberty, \& the pursuit of happiness; that to secure these ends, governments are instituted among men..."

Among various erroneous claims made of Jefferson's thinking, even Professor Jill Lepore's logic in reading these lines might seem odd. She holds that Franklin, as a member of the committee preparing the document, was the one aiming to secularize the message when suggesting the change of "sacred rights" into those of "self-evident," as if one could not hold things sacred on moral grounds only. As philosopher Morton White persuasively showed in 1978, holding anything self-evident was a highly complicated philosophical stand at the time. ${ }^{9}$ Moreover, changing Jefferson's "equal creation" into the form that people were "endowed by their Creator" with their natural rights had a far more extensive opposite effect than what holding certain natural rights sacred could ever have.

What is often overlooked about the document is the meaning of rights being inalienable. By this Jefferson clearly referred to the idea that one was morally bound not to alienate them from oneself. One was obligated to cling to one's rights, as was also indicated in Jefferson's original wording of "the preservation of life, \& liberty, \& the pursuit of happiness." Natural rights were something all free men enjoyed by nature and were obligated to preserve for all the purposes of life, including the right of conscience. This meant that choosing one's religious denomination or restraining from choosing any was also a moral choice. Finally, it is noteworthy that as late as 1813 Jefferson still remained convinced that there were natural rights that had "not yet entered any declaration of rights." ${ }^{10}$ Most probably, he would have added to the list at least the right to education, although we have no definite evidence on the matter.

Was Jefferson serious in claiming that all men are created equal? In terms of mere natural rights, he could well have thought so. There is no evidence

8 See TJ's "original Rough draught" and the parchment copy of the final Declaration of Independence, the latter generally considered the authoritative version of the document, The Papers of Thomas Jefferson, ed. Julian P. Boyd et al. (Princeton: Princeton University Press, 20 vols., Philadelphia, 1950 -) [hereafter cited as Papers]1: 423-427, 429-432.

9 Jill Lepore, These Truths: A History of the United States (New York: W.W. Norton \& Company, 2018), xiv; On the problems of viewing anything properly self-evident in eighteenth-century philosophy, see Morton White, The Philosophy of the American Revolution (New York: Oxford University Press, 1978), 9-21.

10 TJ to John Wayles Eppes, June 24, 1813, Merrill D. Peterson (ed.), Thomas Jefferson Writings (New York: Library of America, 1984) [hereafter cited as TJW], 1282. 
in the Jefferson archive against his thinking that women were also by nature entitled to the rights of life, liberty, and the pursuit of happiness. That American slavery was contrary to these rights Jefferson made abundantly clear. As early as in 1774 he insisted that the "abolition of domestic slavery" had been a "great object of desire" in the colonies. ${ }^{11}$ His condemnation of the international slave trade in the Declaration of Independence was taken out of the final version. ${ }^{12}$ In his Notes on the State of Virginia, written in the early 1780 s, he held that "the whole commerce between the master and slave is a perpetual exercise of the most boisterous passions, the most unremitting despotism on the one part, and degrading submissions on the other." ${ }^{13}$ And Jefferson kept to this faith. As late as 1824 he wished to free and send all American slaves to "some country and climate friendly to human life and happiness," where they could form "a separate, free and independent people."14 "This," he insisted, "was the result of my reflections on the subject five and forty years ago [since 1779], and I have never yet been able to conceive any other practicable plan." 15

That natural rights did not equate to political rights becomes evident given the mere age restrictions of voting in any democracy even today. No one in 1776 yet knew what kind of governments the new American states would establish once they gained their freedom to do so. This is why there is no mention of individuals' political rights in the Declaration of Independence. They were to be decided in states' constitutions. Preparing the Declaration of Independence had interrupted Jefferson in the midst of drafting his own proposal for the Virginia constitution.

In his 1776 draft constitution for Virginia Jefferson suggested general male suffrage alongside the regulation that the upper house of the state legislature would be chosen by those elected to the lower chamber. The suggestion clearly indicated that all white, male free inhabitants of the state were supposed to be equally enfranchised. As for possible property qualifications, Jefferson promoted the extraordinary idea of appropriating 50 acres of land to "every person of full age neither owning nor having owned" such

11 TJ, Summary View of the Rights of British America, 1774, TJW, 115.

12 Eric Slauter, "The Declaration of Independence and the New Nation," in Frank Shuffelton (ed.), The Cambridge Companion, 12-34.

13 Thomas Jefferson, Notes on the State of Virginia (London, 1787 edition), as in TJW [hereafter cited as Notes], Query XVIII, 288.

14 TJ to Jared Sparks, Feb. 4, 1824, TJW, 1484.

15 Ibid., 1485. 
land. Finally, he suggested establishing full religious freedom in the state. ${ }^{16}$ Of all these suggestions, only the idea of religious freedom was politically inconsequential enough for the Virginia establishment, although it was left to Jefferson himself to draft a law that would establish it. He did, and it became the first law of religious freedom in the United States pertaining also to the non-believers.

\section{Political Rights}

Reading the Declaration of Independence, no contemporary could have thought that the ideal of equality would in some automatic sense entail equal political rights. The ideals of the older society of orders lived on for a long time among the founding generation. Jefferson thought that equality might mean giving all adult, white male Virginians the right to vote. His hope was in vain. Virginia did not, against his consistent demands, provide more than approximately half of all free white men the right to vote during his lifetime.

To get the gist of Jefferson's understanding of politics, one should first dismiss his, still surprisingly popular, fame as an advocate of small government. There are serious flaws in, for example, Joyce Appleby's legendary claims of the Jeffersonian movement aiming at a new kind of social ordering of "uniting our affections" instead of an allegedly mere governmental vision of only "restraining our vices," not to mention her claim that the Jeffersonian vision was about "retreat from politics" altogether. ${ }^{17}$ To Jefferson, the Revolution was about establishing a governmental order in which democratic rights would be gradually extended to all free American men. The purpose was that of "making every citizen an active member of the government, and in the offices nearest and most interesting to him," because that would "attach him by his strongest feelings to the independence of his country, and to its republican constitution." ${ }^{18}$ The fashionable byword for the ideal social ordering of the time, the republic, in Jefferson's definition

TJ, Draft Constitution for Virginia, June 1776, TJW, 336-345; The exact wording was that "All male persons" with 25 acres of land and others having paid "scot and lot to government the last [two years] shall have right to give their vote in the election of their respective representatives" as well as to be qualified for any office of government.

17 Joyce Appleby, Capitalism and a New Social Order: The Republican Vision of the 1790s (New York: New York University Press, 1984), quotations, respectively, 33, 23.

18 TJ to Samuel Kercheval, July 12, 1816, TJW, 1399 (emphasis added). 
referred simply to "a government by its citizens in mass, acting directly and personally, according to rules established by the majority." 19 By the same token, Jefferson's famous advocacy of a free press was supposed to disprove the old prejudice "that freedom of the press is incompatible with orderly government." 20

Similarly, Jefferson's famous proclamations about rebellions as natural occurrences in society were not about advocating anti-governmental sentiments. Rebellions were "medicine of the sound health of government." ${ }^{21}$ As for his praising Native Americans living without governments he explicitly referred to their "infinitely greater degree of happiness than those who live under the European governments," hence comparing their political systems to the old world's societies of orders. Among Indians, Jefferson insisted, "public opinion is in the place of law \& restrains morals as powerfully as laws ever did anywhere." 22 This was not to suggest that Americans should dismiss law and order, but that the notion of popular sovereignty was the natural basis for any ordering of a human society under the law of nature.

Jefferson was a champion of small government only in his skepticism about extending the federal government's powers any further than the Constitution explicitly suggested. According to him, the independent states that combined themselves into the form of the federation in 1789 did it only "for the management of their concerns with one another \& with foreign nations, and ... chose to give it powers for those purposes \& no others." ${ }^{.23}$ The legitimate purposes of the federal government were those of national defense, of mediating between the states on boundary disputes, and of specific issues regarding interstate commerce and banking, the last being the major source of Jefferson's bitter rivalry with Hamilton. Throughout antebellum American history, issues such as determining citizenship or religious matters remained exclusively within states' powers. While the strict division between the federal and state powers was elemental to Jefferson's thinking of American democracy, no less elemental was his reliance on local level politics.

19 TJ to John Taylor, May 28, 1816, TJW, 1392 (emphasis added).

20 TJ to Thomas Seymour, Feb. 11, 1807, in Joyce Appleby and Terence Ball (eds.), Thomas Jefferson: Political Writings (New York: Cambridge University Press, 1999), 273 (emphasis added).

21 TJ to James Madison Jan. 30, 1787, TJW, 882 (emphasis added).

22 TJ to Edward Carrington, Jan. 16, 1787, TJW, 880. On Jefferson's speculations about a society without government "as among our Indians" being perhaps the best "condition" for the Americans in general, see TJ to James Madison Jan. 30, 1787, TJW, 882.

23 TJ to Edmund Randolph, Aug. 18, 1799, TJW, 1068-69. 
In Jefferson's eyes, local democracy was a no less political way of doing politics than any other, but an essential aspect of the overall federal system of government of all Americans. This is why Jefferson insisted in 1816-as he had insisted in the early 1780s - that people in every local Virginia community (whether called a ward-republic, a township, or a hundred) should democratically provide a "justice, chosen by themselves, ... a constable, a military company, a patrol, a school, the care of their poor, their own portion of the public roads, the choice of one or more jurors to serve in some court, and the delivery, within their own wards, of their own votes for all elective officers of higher sphere." 24 Through participating in common decision making in one's township every man was simultaneously part of the federal government.

The republican order of government, in fact, obliged every citizen to take responsibility for one's government on both local and federal levels. After all, any such government, on all its levels, always acted in his/her name due to being based on popular sovereignty. All people making decisions were making them for themselves as well as for all the rest of society. As for those devoid of even the right to vote, the privileged few were their representatives. The same had held true of ancient Greek city-state democracies in which only the masters of the households gathered to make decisions on behalf of their wives, servants, slaves, and children.

Jefferson never made up his mind whether or not women were by nature endowed with at least the potential right to vote. Once he encountered a situation in which he could have appointed a woman in public office, he stated only that the "appointment of a woman to office is an innovation for which the public is not prepared, nor am I." ${ }^{25}$ Compared to the situation of any slave household in which the traditional master of the family had no say over even his own fate, women's political rights no doubt appeared a minor problem to Jefferson, something to be solved over time. Notably, Jefferson, who had frequented Paris salons in the 1780s, did not here (or elsewhere) deny the possibility that "the public" might one day find women's political rights to be consistent with the law of nature. ${ }^{26}$

24 TJ to Samuel Kercheval, July 12, 1816, in Paul Leicester Ford (ed.), The Works of Thomas Jefferson, 12 vols. (Federal edition, New York, 1904-1905) [hereafter cited as Ford] 12: 8-9; On the idea of dividing the counties into hundreds, each having a court and militia and the task of taking care of the roads and the poor, see also TJ to John Tyler, May 26, 1810, TJW, 1226; Notes, TJW, Query XIV, 263.

25 TJ to Albert Gallatin, Jan. 13, 1807, Ford 10: 339.

26 That Jefferson would not have heard of Mary Wollstonecraft is practically impossible given that women's rights were widely discussed in the Republican clubs in the 1790s. His huge library included several 


\section{Jefferson's Racism and Moral Concerns}

Associating Jefferson's racism with his allegedly hypocritical antislavery view, or even with his mere "antislavery moments," is still popular among scholars. ${ }^{27}$ That Jefferson was a racist by our standards is beyond question. He held that "the improvement of the blacks in body and mind, in the first instance of their mixture with the whites, has been observed by every one, and proves that their inferiority is not the effect merely of their condition of life." ${ }^{28}$ But he could just as easily hold that "the black man, in his present state, might not be" equal to the white man, whereas "it would be hazardous to affirm, that, equally cultivated for a few generations, he would not become so." 29

Notably, Jefferson was not certain whether even Native Americans were genetically equal to the Europeans. On their genetic background he stated only that "we shall probably find that they are formed in mind as well as in body on the same module with" the European homo sapiens. ${ }^{30}$ With his belief in "the existence of a germ in their minds which only wants cultivation," he never suggested that Native Americans currently lived up to the standards of the civilized nations. ${ }^{31}$

To grasp Jefferson's hesitance on such issues as the genetic potential of any group of people to achieve the Enlightenment-age level of Euro-American civilization, it is good to bear in mind that in contemporary scholarly literature race and species were still widely equated with each other. ${ }^{32}$ This

books on female education. See Sowerby, E. Millicent, comp. Catalogue of the Library of Thomas Jefferson (Washington: Library of Congress, 1952-59) as online at for example, http://www.librarything.com/ catalog.php?view=ThomasJefferson\&deepsearch=women (accessed, June 15, 2020).

27 See, for example, Robert Pierce Forbes's attack on Jefferson as the emblem of all American racism in his "'The Cause of This Blackness': The Early American Republic and the Construction of Race," American Nineteenth Century History, Vol. 13 (1, 2012), 65-94; On "antislavery moments," see Douglas R. Egerton, Gabriel's Rebellion: The Virginia Slave Conspiracies of 1800 and 1802 (Chapel Hill: University of North Carolina Press, 1993), 73; Or, consider Judith Shklar's statement that historian Garry Wills's “apology for Jefferson's airy deportation schemes, which gave the blacks their rights as 'a people,' but not, of course, as 'men,' who were individuals, is condescending and pointless." (Judith Shklar on Inventing America: Jefferson's Declaration of Independence by Garry Wills in The New Republic, Aug. 26, 1978, 32-34). How all this can appear more than "pointless" in terms of a serious historical research is what I try to establish here.

28 Notes, Query XIV, 267.

29 TJ to Chastellux, June 7, 1787, TJW, 801.

30 Notes, Query VI, TJW, 187 (emphasis added).

31 Notes, Query XIV, TJW, 266.

32 That regardless of his racism Jefferson always considered Africans as human beings can be proved by 
is why observable cultural traits remained the main criterion for all such assessments. Jefferson's hope that the Liberian colony of freed slaves could "introduce the arts of cultivated life, and the blessings of civilization and sciences" to the whole African continent speaks to the general conviction of the time that civilization itself was of a European origin and that all others could only adopt it according to the best of their abilities. ${ }^{33}$

That eighteenth-century scholars practically never questioned the supremacy of their own, exclusively Western, cultural background is not that surprising, given our problems in adjusting to any genuinely multicultural values today. ${ }^{34}$ If we assume, as some scholars still argue, that Jefferson's antislavery sentiments served as mere window-dressing for his pathological hatred of Africans, he could have rid himself of the problem by selling his slaves to the West Indies, instead of suggesting their enormously expensive expatriation there as a free people..$^{35}$

As for the ethical aspects of all this, it was clear to Jefferson that no known fact in natural history could justify the enslavement of people of African origin - even if Jefferson's "suspicion only" of their being "originally a distinct race" (an entirely "different species") from other humans was true. ${ }^{36}$ For Jefferson natural rights obligated white society not only to emancipate the slaves, but also to treat the famous Gabriel Prosser's slave rebels with respect. They were "not of the character of common felons, but guilty of insurgency only," and could be sent to Sierra Leone "as free persons." ${ }^{37}$

taking a glance at his wording about slave trade in his original draft of the Declaration of Independence. He stated there that George III was "determined to keep open a market where MEN should be bought \& sold." I thank M. Andrew Holowchak for bringing this rather obvious but often ignored piece of evidence to my attention.

33 TJ to Jared Sparks, Feb. 4, 1824, TJW, 1484.

34 See on the distinctly Western, early notions of scientific progress, Helo, History, Politics, and the American Past, passim., esp. 43-49.

35 See for example, Forbes, “'The Cause of This Blackness,"” 2012; Similarly, Garret Ward Sheldon argues that "Jefferson's ideas and action on slavery ... tell us more about the human capacity for self-deception than anything else" in Sheldon, The Political Philosophy of Thomas Jefferson (Baltimore: Johns Hopkins University Press, 1993), 140; For a forceful interpretation to the opposite, see Arthur Scherr, "Intellectual roots of Thomas Jefferson's opinions on slavery: Montesquieu's impact," Journal of Transatlantic Studies (2021): https://doi.org/10.1057/s42738-021-00068-z (accessed May 19, 2021); For an important discussion on Jefferson's "racism," see also chapter 3 in M. Andrew Holowchak, Rethinking Thomas Jefferson's Views on Race and Slavery (Newcastle upon Tyne: Cambridge Scholars Publishing, 2020), 33-54.

36 Notes, Query XIV, 270.

37 TJ to (Governor of Virginia) James Monroe, June 2, 1802, The Online Library of Liberty at: http://oll. libertyfund.org/title/757/87347 (accessed March 19, 2011). 
Jefferson's understanding of individual rights demanded viewing every one as entitled to freedom of conscience and civil liberties. Like his condemnation of slavery in the Notes on the State of Virginia, his memorandum on Condorcet's stance on the issue made clear that it was against the law of nature for the slave to be deprived of even "the faculties of acquiring" private property, and "that to this wrong is added that of taking from the slave the right to dispose of his person." 38 The background for this crucial notion of every slave deserving "the right to dispose of" one's own "person" lies in Jefferson's virtue ethic, originating in his commitment to Greek eudaimonistic moral thought. ${ }^{39}$

As to eudaimonistic thinking in general, so for Jefferson, happiness was always a consequence of an individual's moral commitment to developing oneself into a virtuous person. For this to occur, every human being needed training, education, and constant exercise of one's faculties so as to attain the highest personal level of intellectual and moral virtues consistent with one's natural inclinations. This notion was clearly present also in Jefferson's famous advocacy of general education. Education was supposed not only to provide all citizens the means for understanding "their rights, to maintain them, and to exercise with intelligence their parts in self-government," ${ }^{40}$ but also to seek out "worth and genius ... from every condition of life." This natural elite would be "completely prepared by education for defeating the competition of wealth and birth for public trusts." 41

From the notion of constant self-betterment also arose Jefferson's frequent counseling of his daughter Martha, and other youngsters he knew, about learning "those principles of virtue and goodness which will make you valuable to others and happy in yourself." ${ }^{2}$ Because self-development alone truly made people individuals within Jefferson's ethical view, slavery - which by definition prevented one from conscious self-bettermentwas not only wrong but unnatural. To correct the situation Jefferson's plan of abolition included the education of slave children before their expatriation. They were to "be brought up, at the public expence [sic], to tillage, arts

39 See for example, Ari Helo, Thomas Jefferson's Ethics and the Politics of Human Progress (New York: Cambridge University Press, 2014), chapter "Progress and the Wise Man's Virtue," 78-108.

40 TJ, Autobiography (1821), TJW, 44.

41 TJ to John Adams, Oct. 18, 1813, AJL, 390 (emphasis added).

42 TJ to Martha Jefferson, May 21, 1787, TJW, 896-897. 
or sciences, ... till the females should be eighteen, and the males twentyone years of age." Given that slaves were individuals by nature just like all other human beings, their education was also to be trimmed "according to their geniuses." 43

In Jefferson's view, morality consisted of two elements, justice and benevolence. Natural rights were rights of justice, something absolutely inviolable. Even as a slaveholder himself, Jefferson once gloomily noted that every revolutionary slaveholder had inflicted on his slaves "a bondage, one hour of which is fraught with more misery than ages of that which he rose in rebellion to oppose." 44 But bringing justice to those still devoid of it under regular laws of the land called for more than mere conventional justice. It called for benevolence. And showing benevolence to the needy, even in the name of sheer justice, was a duty of the politically empowered. In terms of regular representative government based on popular sovereignty, the politically empowered were therefore representatives of themselves and their voting constituency as well as of children, women, immigrants still without citizenship, indentured servants, and slaves. Benevolence, hence, belonged irreconcilably to the Jeffersonian concept of politics.

The dilemma lay solely in the fact that the politically empowered had to recognize the rights of those still devoid of freedom and political rights. One should not underestimate the complexities involved in the concept of representative government. Jefferson once noted about Aaron Burr, whom he always considered a dishonest man, that Burr nevertheless "possessed the confidence of the nation," and that it was therefore Jefferson's "duty to respect in him their confidence, \& to treat him as if he deserved it." 45 As it came to the question of how to solve the problem of slavery, Jefferson's lamentation was this: "There are many virtuous men who would make any sacrifices to affect it [emancipation of slaves], many equally virtuous who persuade themselves either that the thing is not wrong, or that it cannot be remedied." 46

This is the point at which Jefferson's never shaken commitment to law and order becomes fully understandable. For fifty years after the Revolution he vainly called for the extension of democratic rights equally to both rich and poor men in Virginia. Even so, he never disclaimed his obedience

44 TJ, Miscellany, Answer to Jean Nicolas Démeunier, June 26, 1786, TJW, 592.

45 TJ William Branch Giles, Feb. 3, 1807, TJW, 1175.

46 Quotation, TJ to William A. Burwell, Jan 28, 1805, Ford 10:126. 
to the Virginian or the federal governments. Politics under democratic majority rule was, after all, always about peaceful persuasion of one's fellow citizens. And Jefferson never found the needed majority for getting his plan of emancipation put into effect.

\section{Jefferson's Plan for Abolition}

Historian Padraig Riley's book, Slavery and the Democratic Conscience: Political Life in Jeffersonian America (2016), serves as a cautionary example of how moralizing one's topic may lead a professional historian (with all his facts right) to lose the context in which what was in need of explaining might become understandable. Riley's book teems with such empty phraseology as that Northern Jeffersonians, contrary to Southern Jeffersonians, "understood slavery as an institution that embodied unjust power." 47 Thomas Jefferson, who had publicly condemned slavery ever since the War of Independence, hardly belonged among the Northern Jeffersonians. Similarly, the reader must wait for dozens of pages for Riley's passing remark that there were also Federalist slaveholders in the United States.

Worse still, Riley speaks of the highlight of his narrative, the 1820 Missouri Compromise as a crisis for "democracy" in "the American nationstate." 48 Calling the antebellum constitutional federal system a nation-state is historically false, not to mention that American democracy of the time was something entirely different from ours. Otherwise Jefferson would not have demanded that Virginia adopt general suffrage for all white men. The reason he drafted the law of religious freedom for Virginians was that the Constitution did not yet guarantee that states could not infringe that freedom. Elsewhere they continued to infringe it.

Let us think of contextualizing Jefferson's stand on slavery anew. One may begin with Riley, who in fact mentions that slavery was still in force in most of the Northern states throughout Jefferson's life. Even in 1820, during the Missouri crisis, there were 20,000 slaves in the state of New York, 7,000 slaves in New Jersey, and thousands of others in other Northern

47 Padraig Riley, Slavery and the Democratic Conscience: Political Life in Jeffersonian America (Philadelphia: University of Pennsylvania Press, 2016), 68. That Jefferson indeed condemned slavery on several occasions as inhumane is a generally known fact.

48 For the notion of "the American nation-state," see Riley, Slavery and the Democratic Conscience, 204; See also the chapter "Democracy in Crisis," ibid., 199-241. 
states. Moreover, both slaves and freed blacks were occasionally kidnapped from these states to be sold into slavery elsewhere. The reason was that the states had enacted only gradual emancipation laws, to the effect that even New Jersey officially ended slavery only in $1865 .{ }^{49}$ This explains why such confessedly antislavery Virginia leaders as Washington, Jefferson, Madison, and Monroe appeared quite appropriate political allies for most Northerners, even after the Missouri Compromise.

Slavery had been introduced in the country well before Jefferson's birth, and he apparently never imagined that his personal involvement in this hideous practice could be considered criminal or unjust in the conventional meaning of the terms. That people have a natural right to act according to the current laws and practices of their country was hardly ever questioned before such ideas as civil disobedience entered Western political thought. Jefferson's freeing his slaves would not have ended slavery even in Virginia. Neither would his debtors have allowed their emancipation, not to speak of Jefferson not having the funds to send them as free people out of the country. And where would have he sent them?

The commitment to popular sovereignty dictated that such a large-scale act of benevolence as ending slavery in a state would call for democratic solutions. After all, "lex majoris partis is the fundamental law of every society of individuals of equal rights," Jefferson held..$^{50}$ And Jefferson never questioned his own obedience to the Virginia legal order that refused to consent to his will regarding the extension of white men's political rights. Similarly, such non-slaveholding lawyers as John Adams and, later on, even Abraham Lincoln took court cases on behalf of slaveowners claiming back their escaped slaves. As for individuals who deemed the current legal order morally intolerable, Jefferson considered the right to expatriate oneself a natural right of every free man. One was by nature free to find oneself a country without any overwhelming legal or moral problems.

What then was Jefferson's concrete political plan for solving the American problem of slavery? In 1824 he calmly noted that his opinion on the matter had been before the public for almost fifty years. By this he referred

49 See Riley, Slavery and the Democratic Conscience, 52 and Hendrik Hartog, The Trouble with Minna: A Case of Slavery \& Emancipation in the Antebellum North (Chapel Hill: The University of North Carolina Press, 2020), 2-4.

50 TJ to Alexander Humboldt, June 13, 1817, in Appleby Ball (ed.), Thomas Jefferson: Political Writings, 221. 
to his plan in the Notes on the State of Virginia, where it was stated that only the future generations of slave children could be safely emancipated. This entailed that every new generation of Virginia slave children "should continue with their parents to a certain age, then be brought up, at the public expence [sic], to tillage, arts or sciences, according to their geniusses, till the females should be eighteen, and the males twenty-one years of age." After that they were to be "colonized to such place as the circumstances of the time should render most proper, sending them out with arms, implements of houshold [sic] and of the handicraft arts, seeds, pairs of the useful domestic animals, \&c," and be there treated as "a free and independent people." ${ }^{11}$ As Jefferson explained later on, this gradual education and removal process would take approximately fifty years to complete..$^{52}$

Jefferson's motive for the large-scale deportation was only partially racist. He was more concerned about racial violence on the part of probably vengeful freed African Americans against their former masters. Such a fear was directly referred to even in Tocqueville's Democracy in America as well as reflected in Madison's statement that "if the blacks [are] retained among the whites, under the degrading privation of equal rights, political and social, they must be ... always secretly confederated against the ruling and privileged class." 53

As for the emancipated people's future homeland, Jefferson once remarked that he had always considered Africa too distant a place for the purpose.$^{54}$ This explains his constant delving into the affairs of Saint Domingue (later Haiti), which he considered the most convenient resort, and where a black regime had risen in power. To be sure, Jefferson hardly ever considered the Haitian government worth protecting, but rather thought of the country as a potential, long-term protectorate of the United States, in which its former slaves would eventually gain proper political independence.

51 Notes, Query XIV, TJW, 264.

52 TJ to Jared Sparks, Feb. 4, 1824, TJW, 1487.

53 For the quotation, see Drew R. McCoy, The Last of the Fathers: James Madison \& the Republican Legacy (New York: Cambridge University Press, 1996), 279; On Tocqueville's fears about "the most horrible of civil wars and perhaps the extirpation of one or the other of the two races" in the South, see Chapter "The Three Races in the United States" in Alexis de Tocqueville, Democracy in America, Vol. I [De La Démocratie en Amérique, 1835], transl. Henry Reeve \& Francis Bowen. New York: Vintage Books, 1945), esp. 392-397 (quotation, 394).

54 Jefferson insisted that he had never imagined that "any place on the coast of Africa should answer the purpose" of the deportation of all American slaves. TJ to Jared Sparks, Feb. 4, 1824, TJW, 1487. 
As for the alleged naivety of Jefferson's deportation plan, academic criticism of it appears to evolve from scholars' failure to grasp two things. First, they tend to overlook the fact that such an alleged high priest of minimal government as Jefferson in fact suggested huge tax increases to cover the compulsory deportation. Second, scholars tend to forget that the cotton boom that created the antebellum kingdom of cotton - and the consequent, unfortunate development of Southern slavery into a surprisingly efficient labor arrangement for large-scale raw material production-was not yet even a vision during Jefferson's lifetime.

That the solution had to be political, and political on the level of every slave state itself, is best exemplified in Jefferson's counselling one Edward Coles against moving with his few slaves from Virginia so as to free them in Illinois territory. By contrast, Jefferson urged Coles to stay alongside such slaveholders as Madison and himself so as not to lessen the state's "stock of sound disposition," and just continue coming "forward in the public councils" to persuade the political elite "softly but steadily" to change their mind about the issue. ${ }^{55}$

Jefferson's political record regarding the issue of slavery is not worse than that of most of the twelve first American presidents, of whom ten were slaveholders. As noted, he spoke against the international slave trade during the Revolution and suggested banning slavery in Virginia in the early 1780s. His draft of the 1787 Northwest Ordinance included the prohibition of slavery in any new state to be formed out of that area. It was also during Jefferson's presidency that the United States prohibited the international slave trade. He remained in correspondence with all antislavery factions in the country, including the Colonization Society as well as with a few free African Americans. Jefferson never went into all details of how to achieve the abolition and wholesale deportation so as to avoid political quarrels focusing only on details. But he consented to the idea of requiring slaveholders to give up their slave children for a modest compensation by the states by the means of selling federal lands in the West. ${ }^{56}$

Why did Jefferson fail to use all his political capital for the abolition of slavery? After his return from France, he soon grew afraid that the Federalists would nullify all states' rights and turn the country into a British ally against all the good things that the French Revolution appeared to represent, 
including the French 1789 Declaration of the Rights of Man. Then came the 1798 Alien and Sedition Acts of the Adams administration, clearly the federal government's attempt at unconstitutional censorship laws. In general terms, it appeared that the Federalist conservatives would have gladly hindered all reforms toward the extension of democratic rights in the United States. When Maryland established general male suffrage without any property qualifications in 1803, Supreme Court Justice Samuel Chase declared that such a reform would "certainly and rapidly destroy all protection of property, and all security to personal liberty; and our republican constitution will sink into a mobocracy, the worst of all possible governments." ${ }^{57}$

Then came the "Revolution of 1800" and the 1803 Louisiana Purchase as well as the long-term diplomatic struggle to keep the Atlantic trade open to the United States during the Napoleonic Wars, a struggle eventually leading to the War of 1812. During the twenty-five-year "bellum omnium in omnia of Europe" Jefferson declared that "the last hope of human liberty in this world rests on us." ${ }^{58}$ And after those wars, the victors only hastened to reestablish all aristocratic privileges and the old continental balance of powers throughout Europe. By further forming the Holy Alliance they aimed to lure church authorities to bless the ancient regime as once again a holy and God-given everywhere. No wonder Jefferson declared these arrangements to be nothing but a new "cloud of barbarism and despotism," threatening "science and liberties" of the genuine Enlightenment tradition. ${ }^{59}$

\section{Jefferson's Changing Views of Slavery}

Annette Gordon-Reed and Peter Onuf have recently argued that Jefferson's views of slavery essentially softened in France, meaning that he did not any more see the abolition as urgent as earlier.$^{60}$ Jefferson's original plan for emancipation (from approximately 1779) was both costly and timeconsuming - and changed only in one respect during his entire life. From approximately 1810 onward Jefferson thought that slavery may extend to the west before its final destruction.

57 For the quotation, see Dumas Malone, Jefferson the President, First Term. Jefferson and His Time, Vol. 4 (Charlottesville: University of Virginia Press, 2005), 466.

58 TJ to William Duane, March 28, 1811 in Founders Online at https://founders.archives.gov/ documents/ Jefferson/03-03-02-0378 (accessed June 24, 2020).

59 TJ to John Adams, Sept. 12, 1821, AJL, 575.

60 See Annette Gordon-Reed \& Peter S. Onuf, “Most Blessed of the Patriarchs": Thomas Jefferson and the Empire of the Imagination (New York: Liveright, W.W. Norton \& Company, 2017). 
In 1789 Jefferson wrote a letter that has led many scholars to speculate that he occasionally could imagine consenting to a vision of an equal, multiracial America, even if only to fall back to his old prejudiced vision of the compulsory expatriation of all African Americans. This letter, written in Paris to Edward Bancroft, is exceptional in suggesting that Jefferson envisioned a scheme of bringing German peasants to Monticello and turn them alongside his slaves as half-independent tenants on his lands. He also made an astonishing suggestion that " $[\mathrm{t}]$ heir children shall be brought up, as others are, in habits of property and foresight, and I have no doubt but that they will be good citizens. Some of their fathers will be so: others I suppose will need government." 61

But did Jefferson mean that both German and African American children would grow into citizenship? Given all other evidence in the Jefferson archive, it is highly unlikely that he even here imagined that. Rather, his formulations about "their children" and "some of their fathers" most likely denoted only the German immigrants, meaning that slave children were only to be educated to tillage and other farming skills until freed and removed out of the state of Virginia.

Notable here is also the fact that during the interim neither Germans nor slaves would have enjoyed full civil rights, given that they obviously as "metayers" would not be allowed to leave their tenant farms. Jefferson's willingness to consider the old world's society of orders as a possible mid-stage for bringing immigrants into citizens may appear surprising. But as noted, indentured servants were still pouring into the country and manorialism flourished in many northern states. Jefferson's numerous sceptic statements on both free African Americans' and newly arrived European immigrants' capabilities for successfully integrating into American society also speaks for this sceptic interpretation of the letter. ${ }^{62}$

Even if there was no change of mind in 1789, how did Jefferson come to believe - glaringly against his old convictions - that spreading slavery in

61 TJ Edward Bancroft, Jan. 26, 1789, Papers 14: 492.

62 In the early 1780 s, Jefferson warned his fellow Virginians that if recently arrived immigrants were allowed to influence the governmental institutions as full citizens would "their spirit, warp and bias its direction," and turn it an "incoherent distracted mass." Notes, Query VIII, TJW, 211; Similarly, in Jefferson's early drafts for Virginia laws any immigrant "vagabonds" from abroad and from other American states were also excluded from Virginia citizenry. TJ, Bill No. 55, A Bill Declaring Who Shall Be Citizens of This Commonwealth, Papers 2: 477; For an earlier, similar interpretation of the Bancroft letter, see Helo, Thomas Jefferson's Ethics, 154-155. 
the West might help the general abolition and compelled expatriation? In the early 1780 s he had confidently written that "the spirit of the master" was already "abating," probably in reference to the gradual emancipation laws all over the Northern states. ${ }^{63}$ By the 1820 Missouri Compromise, nothing of the kind had yet happened in the South. As Madison noted, however, "the states holding fewest slaves are those which most readily abolished slavery altogether," 64 so too was Jefferson convinced that removing part of the slave population out of the largest slave states would help in changing the tide.

Jefferson's fierce opposition to the Missouri Compromise evolved from his conviction that every slave state must abandon the system on its own. Were Virginia, the most populous Southern state, successful in this, the rest of the South would follow suit. It also appears clear that at least the majority of freed men were to be persuaded to move as well. But the idea that the federal Congress would begin to regulate states' laws of citizenship was not only against the current Constitution, but against Jefferson's deepest convictions on how to keep America progressive. He never suggested that the federal government (or any other authority) could compel other states to adopt similar law of religious freedom as Virginians had managed to adopt. Indeed, such laws remained exceptional in the United States.

Keeping in mind Jefferson's commitment to popular sovereignty within the current, constitutional balance between states rights and the powers of the federal government his stand on the extension of slavery to the west is easy to grasp. After all, even partial benevolence was never to hurt those devoid of it: "Moral the question certainly is not," Jefferson held, "because the removal of slaves from one state to another, no more than their removal from one country to another, would never make a slave of one human being who would not be so without it." 65 Contrary to Lincoln, Jefferson simply did not have a federal plan to end slavery.

The only aspect concerning the federal government in Jefferson's plan had to do with financing and sending slaves abroad after each state's individual decision of emancipation. Lincoln aimed at restricting the system of slave labor to the Southern states, not abolishing it against the letter of the Constitution as it stood at the time. Lincoln could be fairly certain that

63 Notes, Query XVIII, 289.

64 James Madison to Robert Walsh, Nov. 27, 1819, Jack N. Rakove (ed.), James Madison Writings (New York: Library of America, 1999), 743.

65 TJ to Albert Gallatin, Dec. 26, 1820, TJW, 1449. 
slavery - which had only recently grown into an effective labor arrangement for raw material production in the current system of international industrial capitalism-would inevitably suffocate there over time. It would lack the primary requirement of any capitalistic endeavour, the prospect of expansion.

All in all, Jefferson was deadly serious in his opinion that slavery must go. The reason he did not end slavery in Monticello was that ending it privately would not have helped. Instead, it would have worsened the situation regarding his ultimate purpose of establishing an independent nation for all the African Americans. He could probably free a few of his slaves so as to send them abroad - though by no means all of them without his debtors intervening - had he sold both his unprofitable mansions and lived in poverty for the rest of his life. He did not, that is his sin. Either way, he was bankrupt when he died and Monticello slaves were sold to slavery elsewhere.

To conclude, Jefferson insisted that he had "never believed there was one code of morality for a public; and another for a private man." ${ }^{\prime 66}$ But he was also aware of the fact that majority democracy would remain a moral compromise. To grasp Jefferson's stand on natural rights as distinct from political rights the issue must be considered in the general eighteenth-century context of intellectual history and political realities of the time. Similarly, his stand on racial issues and women's rights must be considered in the larger context of the mainstream Enlightenment, just as his stand on slavery must be considered in view of his commitment to popular sovereignty within the contemporary, antebellum constitutional balance between states' rights and the powers of the federal government.

Jefferson could have done more, particularly concerning the problem of slavery. He did not. But in one crucial sense one may still agree with his position: the better world is always ours to achieve (even in the face of challenges such as climate change), but that is unlikely if we lose hold of majority democracy or of the individual's right to openly disagree with that majority.

Finally, one may ask after the lasting effects of Jefferson's legacy in all this. They are few simply because the United States revolutionized its own constitution in 1868 by the 14th amendment that, for the first time in entire American history, provided the federal government the powers to dictate on the issues of citizenship over the state legislatures. Jefferson certainly did 
not hope for the kind of social order the United States gained after saving the Union in 1865, a system-blessed by the national Supreme Court in 1896-in which the color of your skin could still determine even an individual's right to vote. As we all know, changing that system according to Martin Luther King's famous dream of the Americans living out Jefferson's words about equality in the Declaration of Independence, took full a hundred years after the Civil War to begin to be actualized. We now know that it took a terrible war for the Americans to end slavery. And war is never but a complete failure of politics. 


\section{Works cited}

\section{PRINTED SOURCE MATERIAL}

Appleby, Joyce \& Terence Ball, eds., Thomas Jefferson: Political Writings. New York: Cambridge University Press, 1999.

Ford, Paul Leicester Ford, ed., The Works of Thomas Jefferson, 12 vols. (Federal edition, New York, 1904-1905)

Freeman, Joanne B., ed., Alexander Hamilton Writings. New York: The Library of America, 2001.

The Papers of Thomas Jefferson, ed. Julian P. Boyd et al. Princeton: Princeton University Press, 20 vols., Philadelphia, 1950-.

Peterson, Merrill D., ed., Thomas Jefferson Writings. New York: Library of America, 1984.

Rakove, Jack N., ed., James Madison Writings. New York: Library of America, 1999.

Tocqueville, Alexis de, Democracy in America, Vol. I [De La Démocratie en Amérique, 1835], transl. Henry Reeve \& Francis Bowen. New York: Vintage Books, 1945.

\section{WEBSITE MATERIAL}

Founders Online at https://founders.archives.gov/documents/Jefferson/03-03-02-0378 (accessed June 24, 2020)

Miller, Andrea, Editorial "The contradictory life and legacy of Thomas Jefferson" in Texarkana Gazette, Dec. 21, 2012 at https://www.texarkanagazette.com/news/ opinion/editorials/story/2012/dec/21/contradictory-life-and-legacy-thomjeffers/264524/ (accessed May $28,2020)$.

Monticello Organization (Thomas Jefferson Foundation) Website, "Thomas Jefferson: Liberty \& Slavery at https://www.monticello.org/slavery-at-monticello/liberty-slavery (accessed May 27, 2020).

The Online Library of Liberty at: http://oll.libertyfund.org/title/757/87347 (accessed March 19, 2011)

Arthur Scherr, “Intellectual roots of Thomas Jefferson's opinions on slavery: Montesquieu's impact." Journal of Transatlantic Studies (2021) at: https://doi.org/10.1057/s42738-02100068-z (accessed May 19, 2021).

Sowerby, E. Millicent, comp. Catalogue of the Library of Thomas Jefferson. Washington: Library of Congress, 1952-59 at: http://www.librarything.com/ catalog.php?view=Thom asJefferson\&deepsearch=women (accessed, June 15, 2020).

\section{LITERATURE}

Appleby, Joyce, Capitalism and a New Social Order: The Republican Vision of the 1790s. New York: New York University Press, 1984.

Egerton, Douglas R., Gabriel's Rebellion: The Virginia Slave Conspiracies of 1800 and 1802. Chapel Hill: University of North Carolina Press, 1993.

Forbes, Robert Pierce, “'The Cause of This Blackness': The Early American Republic and the Construction of Race." American Nineteenth Century History, Vol. 13 (1, 2012), 6594.

Gordon-Reed, Annette \& Peter S. Onuf, "Most Blessed of the Patriarchs": Thomas Jefferson and the Empire of the Imagination. New York: Liveright, W.W. Norton \& Company, 2017.

Helo, Ari, History, Politics, and the American Past: Essays on Methodology. New York: Routledge, 2020. 
Helo, Ari, Thomas Jefferson's Ethics and the Politics of Human Progress: The Morality of a Slaveholder. New York: Cambridge University Press, 2014.

Holowchak, M. Andrew, Rethinking Thomas Jefferson's Views on Race and Slavery. Newcastle upon Tyne: Cambridge Scholars Publishing, 2020.

Lepore, Jill, These Truths: A History of the United States. New York: W.W. Norton \& Company, 2018.

Levy, Leonard W. Levy, "Civil Liberties" in Peterson (ed.), Thomas Jefferson: A Reference Biography, 1986, 331-348.

Levy, Leonard, Jefferson and Civil Liberties: The Darker Side. Cambridge, MA.: Harvard University Press, 1963.

Matthews, Richard K., The Radical Politics of Thomas Jefferson: A Revisionist View. Lawrence: University Press of Kansas, 1984.

McCoy, Drew R., The Last of the Fathers: James Madison \& the Republican Legacy. New York: Cambridge University Press, 1996.

McCurdy, Charles W., Anti-Rent Era in New York Law and Politics, 1839-1865. Chapel Hill: University of North Carolina Press, 2001.

Onuf, Peter, ed., Jeffersonian Legacies. Charlottesville: University of Virginia Press, 1994.

Peterson, Merrill D., ed., Thomas Jefferson: A Reference Biography. New York: Charles Scribner's Sons, 1986.

Riley, Padraig, Slavery and the Democratic Conscience: Political Life in Jeffersonian America. Philadelphia: University of Pennsylvania Press, 2016.

Sheldon, Garrett Wald, The Political Philosophy of Thomas Jefferson. Baltimore: Johns Hopkins University Press, 1993.

Shklar, Judith, Review of Inventing America: Jefferson's Declaration of Independence by Garry Wills in The New Republic, Aug. 26, 1978, 32-34.

Shuffelton, Frank, ed., The Cambridge Companion to Thomas Jefferson. New York: Cambridge University Press, 2009.

White, Morton, The Philosophy of the American Revolution. New York: Oxford University Press, 1978. 